УДК 621.914 .22

DOI: https://doi.org/10.26642/ten-2021-1(87)-13-20

\author{
Г.М. Виговський, к.т.н., проф. \\ О.А. Громовий, к.т.н., доц. \\ Н.О. Балицька, к.т.н., доц. \\ Л.С. Глембоцька, к.т.н., доц. \\ Державний університет «Житомирська політехніка»
}

\title{
Удосконалення процесу чистового торцевого фрезерування плоских поверхонь деталей малої ширини
}

\begin{abstract}
При фінішній обробиі матеріалів високої твердості все більш широке застосування знаходять ториеві фрези, оснащені надтвердими матеріалами, які повністю розкривають свій потенціал при високошвидкісній обробиі. Однак вітчизняним машинобудівним підприємствам не завжди доступне металообробне обладнання такого рівня. Наслідком иього є застосування ториевих фрез, оснащених надтвердими матеріалами, при нераціональних занижених режимах різання, щзо зумовлює зменшення продуктивності обробки, періоду стійкості інструментів та погіршення якості оброблених поверхонь деталей. У роботі досліджуються особливості процесу фінішної обробки поверхонь заготовок малої ширини (20...50 мм), які виготовлені з матеріалів високої твердості, ториевими фрезами, оснащеними надтвердими матеріалами. Показано, щьо процес обробки характеризується неоптимальними режимами різання; використанням фрез малого діаметра; малою кількістю різальних елементів, щио одночасно беруть участь у різанні, та погіршеною динамікою; низькою зносостійкістю різальних елементів; недостатньою продуктивністю обробки та якістю оброблених поверхонь. Встановлено, щзо значні переваги мають прочеси чистової обробки плоских поверхонь косокутними торцевими фрезами з використанням ступінчастих схем різання, які дозволяють забезпечити повну участь у процесі обробки всіх різальних елементів, покращити динаміку процесу та підвищити стійкість інструмента. Застосування безвершинної геометрії 3 монотонними криволінійними різальними кромками дозволяє виключити із прочесу формування мікронерівностей найбільш вразливу ділянку різальної кромки - вершину. Визначено шляхи підвищення продуктивності обробки поверхонь малої иирини застосуванням ториевих фрез збільшеного діаметра на невисокошвидкісних верстатах та зміщенням деталей відносно осі фрези на відстань, щсо гарантує забезпечення необхідної висоти мікронерівностей обробленоі поверхні.
\end{abstract}

Ключові слова: ториеве фрезерування; ториева фреза; косокутне різання; ступінчасті фрези; різальні елементи.

Постановка проблеми. Значну кількість деталей, що підлягають чистовій фінішній обробці, становлять планки, напрямні, важелі, стояки, державки тощо. Зазначені деталі мають відносно невелику ширину та, у низці випадків, значну довжину з високими вимогами щодо якості обробки плоских поверхонь.

Здебільшого відповідальні поверхні зазначених деталей обробляються чорновим фрезеруванням 3 подальшим шліфуванням. При цьому процеси плоского шліфування характеризуються можливими дефектами поверхневого шару у зв'язку 3 високотемпературним характером різання та значними зусиллями різання. Також виникають труднощі забезпечення необхідної шорсткості обробки за всією довжиною деталей, пов'язані зі зносом абразивних кругів, особливо при обробці деталей, виготовлених 3 матеріалів високої твердості. Процеси абразивної обробки, як відомо, відрізняються значно меншою продуктивністю по відношенню до процесів чистового торцевого фрезерування (у $3 \ldots 5$ разів).

В останній час широке розповсюдження знайшли методи фінішної обробки плоских поверхонь чистовими торцевими фрезами, оснащеними надтвердими матеріалами (НTM). Обробці підлягає низка точних відповідальних поверхонь, від якості обробки яких залежать необхідні характеристики контактної жорсткості, зносостійкості, надійності механізмів та машин.

Разом 3 тим, широке розповсюдження процесів чистового торцевого фрезерування для обробки поверхонь малої ширини гальмується тим, що раціональне використання торцевих фрез, оснащених НТМ, потребує застосування оптимальних значень швидкості різання. Проте існуючі металорізальні верстати здебільшого працюють 3 частотами обертання, які не перевищують 2000 хв$^{-1}$, що призводить до чистової обробки плоских поверхонь на неоптимальних режимах різання, зменшення періоду стійкості інструментів та погіршення якості обробки. Крім цього, малі значення подачі на зуб та зменшені частоти обертання шпинделів верстатів (відносно можливих оптимальних значень швидкості різання) призводять до зменшення хвилинної подачі та продуктивності обробки. 
Дослідження питань підвищення якості та продуктивності обробки поверхонь малої ширини чистовими торцевими фрезами, оснащеними НТМ, на традиційних верстатах невисоких швидкостей $є$ важливим завданням машинобудування.

Аналіз останніх досліджень та публікацій. У дослідженнях розглянуто питання чистової обробки плоских поверхонь чавунних та стальних загартованих деталей з використанням торцевих фрез нових конструкцій, оснащених НТМ [1-3]. Авторами встановлено високу ефективність розроблених фрез для обробки деталей, що працюють в умовах змінних навантажень, інтенсивного тертя та високих температур. Застосування торцевих фрез, оснащених НТМ, дало можливість відмовитися від процесів фінішної абразивної обробки плоских поверхонь, що дозволило значно підвищити продуктивність обробки та зменшити дефекти поверхневих шарів.

Переважна більшість конструкцій чистових торцевих фрез, оснащених НТМ, реалізує генераторну схему різання 3 розподілом припуску за подачею. Як наслідок, похибки взаємного розташування різальних елементів у поєднанні з малими подачами на оберт $(0,02 \ldots 0,04$ мм/об) призводять до неучасті частини різальних елементів у різанні та погіршення динаміки процесу фрезерування. При цьому у більшості випадків використовується стандартна геометрія різальних елементів, що зменшує період стійкості фрез та якість обробки.

Застосування для торцевих фрез, оснащених НТМ, ступінчастих схем різання [6-7] і косокутної геометрії різальних елементів дозволяє суттєво підвищити якість фрезерованих поверхонь, зменшити час обробки деталей та збільшити період стійкості інструментів. Задача підвищення продуктивності виготовлення деталей особливо важлива для процесів, що здійснюються на високошвидкісних верстатах та верстатах з числовим програмним управлінням, де складова вартості верстато-хвилин у собівартості обробки деталі є дуже високою.

При конструюванні торцевих фрез, оснащених НТМ, для виготовлення плоских поверхонь деталей основними вихідними даними є вид та матеріал деталі, вимоги до якості обробленої поверхні, технічні характеристики верстата. Ефективність роботи торцевими фрезами визначається їх конструктивним виконанням, раціональними схемами зрізання припуску, оптимальною геометрією різальних елементів (PE), способом базування фрез на верстатах та інструментальним матеріалом.

Аналіз режимів різання чистовими торцевими фрезами, оснащеними НТМ, показує, що рекомендовані значення швидкості різання при обробці чавунів та кольорових металів коливаються у широких межах від 1000 до 2000 м/хв. Для чистової обробки площин застосовуються малі значення подачі на зуб. Це пояснюється тим, що фактично оброблену поверхню при використанні генераторної схеми різання формує один РЕ, який має максимальну величину осьового вильоту (мінімальна величина подачі на зуб складає 0,005 мм/зуб, а для більшості конструкцій фрез вона становить $0,01 \ldots 0,04$ мм/3уб). Глибина різання встановлюється залежно від виду обробки та коливається в межах від 0,05 до 2 мм для напівчистового і чистового фрезерування.

За критерієм зносостійкості для процесу чистового торцевого фрезерування найбільш використовуваними є такі надтверді інструментальні матеріали, як гексаніт, ельбор, киборит. Зазначені інструментальні матеріали забезпечують можливість здійснювати обробку при високих швидкостях різання та зберігати високу різальну здатність. Разом з тим, при збільшених припусках на обробку на різальних кромках можливе виникнення термічних тріщин, які перпендикулярні головним різальним кромкам, що призводить до викришування частинок інструментального матеріалу і катастрофічного зносу та вимагає пошуку раціональних форм та геометрії РЕ фрез.

Експериментально обгрунтовано, що одним зі шляхів підвищення працездатності торцевих фрез, оснащених НТМ, є використання косокутної геометрії РЕ, що призводить до збільшення кутів сходу стружки, збільшення робочих передніх кутів інструмента та довжини активних частин різальних кромок, а це зменшує питомі навантаження на одиницю довжини різальної кромки та збільшує їх зносостійкість. Для чистової обробки плоских поверхонь деталей підтверджено ефективність використання косокутної геометрії ножів фрез з від'ємними кутами нахилу різальних кромок та застосуванням задніх циліндричних поверхонь РЕ.

Результати впровадження чистових торцевих фрез косокутного різання у виробництво показали підвищення продуктивності обробки по відношенню до шліфування (у 4..6 разів) та фрез стандартних конструкцій (у $3 \ldots 5$ разів).

Косокутні ступінчасті торцеві фрези, оснащені НТМ, використовуються для чистової обробки чавунів, загартованих сталей та кольорових сплавів, при цьому ширина фрезерування здебільшого становить від 100 до 400 мм. Разом з тим, необхідність чистової обробки деталей малої ширини (20...50 мм) ставить задачу пошуку раціональних технологій фрезерування із забезпеченням необхідної висоти мікронерівностей та підвищення продуктивності процесу порівняно зі стандартними фрезами, оснащеними НТМ. 
Дослідження та вирішення розглянутих питань, які спрямовані на підвищення працездатності косокутних ступінчастих торцевих фрез, оснащених НТМ, для чистової обробки плоских поверхонь деталей малої ширини є актуальним завданням і має велике значення для машинобудування.

Мета дослідження - пошук шляхів підвищення якості обробки плоских поверхонь малої ширини косокутними ступінчастими торцевими фрезами, оснащеними надтвердими матеріалами, збільшення продуктивності обробки за рахунок раціонального вибору діаметра торцевих фрез, розміщення фрез відносно оброблюваної поверхні та використання раціональних режимів різання на верстатах, що мають частоти обертання шпинделя до $2000 \mathrm{xB}^{-1}$.

Викладення основного матеріалу. Проєктування технологічного процесу чистової обробки плоских поверхонь деталей торцевими фрезами, оснащеними НТМ, містить основні етапи, серед яких: вибір різального інструменту, встановлення режиму обробки та схеми розміщення інструменту відносно заготовки.

Конструкція торцевих фрез, оснащених НТМ, визначається такими параметрами:

- діаметр фрези;

- кількість різальних елементів;

- геометричні параметри різальних елементів;

- інструментальний матеріал;

- схема різання;

- спосіб закріплення різальних елементів у корпусі фрези;

- спосіб базування та закріплення фрези у шпинделі верстата.

У дослідженнях [5-11], виконаних авторами з Державного університету «Житомирська політехніка», розглянуто питання раціональних технічних рішень щодо конструкцій торцевих фрез для чистової обробки деталей із загартованих сталей, чавунів та кольорових металів і забезпечення високої якості та продуктивності обробки. Встановлені значні переваги сконструйованих фрез $з$ використанням ступінчастих схем різання, що дозволяють забезпечити повну участь у різанні всіх різальних елементів та підвищити зносостійкість інструменту. При цьому покращується динаміка процесу фрезерування та його надійність за рахунок зменшення випадків катастрофічного виходу з ладу різальних елементів, що $\epsilon$ характерним для стандартних конструкцій фрез зі схемою різання з розподіленням припуску за подачею [12-15].

Застосування традиційної геометрії різальних елементів для стандартних фрез з головною та допоміжною різальними кромками, які спряжені відносно малою радіусною ділянкою $(0,8 \ldots 1,2$ мм), призводить до підвищених навантажень в області вершини. Це $є$ причиною швидкого виходу 3 ладу РЕ та викликає необхідність використання низьких значень подач на зуб (0,02 ..0,04 мм/зуб). Малі радіуси при вершині та використання мінімальних подач суттєво зменшують продуктивність та підвищують собівартість обробки деталей.

Для інтенсифікації режимів різання та зносостійкості різальних елементів дослідженням [6] встановлена раціональна геометрія РЕ: монотонні криволінійних різальні кромки 3 відсутністю концентратора зносу, радіуси задньої циліндричної поверхні $8 \ldots 12$ мм, передній кут $\gamma=-8^{\circ}$, кут нахилу різальної кромки $\lambda=-30^{\circ} \ldots-45^{\circ}$. Косокутна безвершинна геометрія РЕ дозволяє полегшити процеси зрізання мінімальних товщин зрізуваних шарів, які характерні для чистового різання, а монотонні різальні кромки відносно великих радіусів - зменшити навантаження на одиницю довжини кромки, що підвищує зносостійкість та продуктивність обробки.

Разом $з$ тим, при обробці плоских поверхонь заготовок малої ширини чистовими торцевими фрезами характеристики процесу різання мають свої особливості (рис. 1).

\begin{tabular}{|c|c|c|c|}
\hline \multicolumn{4}{|c|}{ Особливості процесу обробки поверхонь заготовок малої ширини торцевими фрезами } \\
\hline & & & \\
\hline $\begin{array}{c}\text { Використання } \\
\text { неоптимальних } \\
\text { швидкостей різання }\end{array}$ & $\begin{array}{c}\text { Використання фрез } \\
\text { малого діаметра }\end{array}$ & $\begin{array}{c}\text { Малі значення подачі } \\
\text { на оберт та частоти } \\
\text { обертання фрез }\end{array}$ & $\begin{array}{c}\text { Низька якість } \\
\text { обробки }\end{array}$ \\
\hline $\begin{array}{c}\text { Низькі зносостійкість РЕ } \\
\text { та надійність процесу }\end{array}$ & $\begin{array}{c}\text { Мала кількість РЕ, що } \\
\text { одночасно беруть } \\
\text { участь у різанні, та } \\
\text { погіршена динаміка } \\
\text { процесу }\end{array}$ & $\begin{array}{c}\text { Недостатня } \\
\text { продуктивність } \\
\text { обробки }\end{array}$ & $\begin{array}{c}\text { Неоднорідність } \\
\text { фізико-механічних } \\
\text { характеристик та } \\
\text { шорсткості } \\
\text { оброблених } \\
\text { поверхонь }\end{array}$ \\
\hline
\end{tabular}

Рис. 1. Особливості процесу ториевого фрезерування поверхонь заготовок малої иирини 
Чистова обробка плоских поверхонь торцевими фрезами, оснащеними НТМ, переважно здійснюється за схемою неповного фрезерування, коли діаметр фрези обирається більшим, ніж ширина поверхні деталі, що оброблюється, при цьому рекомендоване співвідношення діаметра торцевої фрези та ширини деталі становить $1,1 \ldots 1,25$. Тому, наприклад, для обробки поверхні шириною 100 мм використовується фреза діаметром 125 мм, за рекомендованої швидкості різання $1200 \ldots 1500$ м/хв для обробки чавунів частота обертання такої торцевої фрези повинна бути $3060 \ldots 3820$ хв$^{-1}$, що вимагає застосування високошвидкісного обладнання. Разом 3 тим, переважна більшість сучасного обладнання має максимальну частоту обертання шпинделя до $2000 \mathrm{xB}^{-1}$. Тому фрезерування деталей малої ширини часто проводиться з неоптимальними швидкостями різання, що призводить до низької зносостійкості торцевих фрез, а підвищений знос РЕ - до появи мікротріщин на передніх та задніх поверхнях РЕ, непрогнозованих явищ їх катастрофічного зносу та низької надійності процесу обробки, що особливо важливо під час обробки деталей складної форми та за високих вимог до якості обробки.

Дослідженням [6] встановлено, що при обробці чистовими торцевими фрезами, оснащеними НТМ, швидкість різання суттєво впливає на шорсткість оброблених поверхонь деталей з різними фізикомеханічними властивостями (табл. 1).

Табличя 1

Залежність шорсткості плоских поверхонь, оброблених ториевими фрезами, від швидкості різання

\begin{tabular}{|c|c|c|c|c|c|c|c|}
\hline \multirow{2}{*}{ Оброблюваний матеріал } & \multicolumn{7}{|c|}{$R_{Z}$ (мкм) при швидкості різання $V$ (м/с) } \\
\cline { 2 - 8 } & 0,81 & 1,30 & 2,06 & 3,22 & 5,02 & 8,01 & 10,40 \\
\hline Чавун СЧ21 & 2,402 & 2,338 & 1,396 & 1,183 & 0,785 & 0,783 & 0,760 \\
\hline
\end{tabular}

Iз даних (табл. 1) видно, що під час обробки деталей на низьких швидкостях різання висота мікронерівностей буде більша, ніж при обробці на максимальних швидкостях різання, тому використання торцевих фрез на низьких швидкостях різання обмежує можливості отримання деталей високої якості.

При обробці деталей шириною до 50 мм діаметр торцевої фрези здебільшого знаходиться у межах 60...80 мм. Закріплення РЕ здійснюється різними способами, але механізм кріплення займає достатньо багато місця для розміщення, тому конструктивно не вдається розмістити велику кількість РЕ на фрезах малого діаметра (для фрез діаметром 60...80 мм кількість РЕ звичайно не перевищує 4...5). Тому у зоні контакту торцевої фрези із заготовкою одночасно участь у різанні беруть один чи два РЕ. В такому випадку процес фрезерування характеризується значними ударами при вході/виході різальних елементів у/із зони різання, що викликає нерівномірні силові навантаження на технологічну систему i, як наслідок, на всі характеристики процесу різання.

Для більшості конструкцій стандартних фрез [1-4] величина подачі на зуб $S_{z}=0,01 \ldots 0,04$ мм/зуб, що вимагає підвищених вимог до точності взаємного розташування РЕ. Але за рахунок похибок базування та закріплення фрез на верстатах, осьового та радіального биття шпинделів верстатів, похибок виготовлення, заточки та установки РЕ фрез сумарне биття різальних кромок може значно перевищувати подачу $S_{z}$. Це призводить до участі в різанні обмеженої кількості РЕ, формування поверхні деталі одним (найбільш виступаючим) РЕ, що знижує стійкість фрез та продуктивність обробки. Малі значення подач та занижені відносно оптимальних частоти обертання торцевих фрез зменшують величину хвилинної подачі та збільшують час обробки деталей.

При торцевому чистовому фрезеруванні необхідно враховувати що, незалежно від кількості різальних елементів фрези, формування обробленої поверхні здійснюється тільки одним РЕ, який має найменшу відстань до обробленої поверхні. Це пояснюється тим, що розташувати всі різальні елементи в одній площині щодо значень шорсткості обробки технічно неможливо. Але, якщо навіть випадково РЕ будуть розташовані в одній площині, при подальшому закріпленні фрези у шпинделі верстата завжди виникають похибки базування і закріплення, що призводить до перекосів фрези і неоднозначного розташування РЕ в одній площині. Положення ускладняється також тим, що осі шпинделів верстатів мають відхилення перпендикулярності відносно площини столів верстатів і мають радіальні та осьові биття, що також змінює положення фрези у просторі. Ще одним фактором, який суттєво впливає на положення торцевих фрез у процесі різання, є теплові деформації шпинделя верстата, які змінюються у часі. А незначний вплив кількості різальних елементів на шорсткість обробки проявляється тільки за рахунок зменшення коливань сил різання та покращення динаміки процесів врізання різальних елементів та їх виходу із зони різання.

Під час чистової обробки ступінчастими торцевими фрезами косокутного різання (рис. 2) оброблену поверхню формує тільки один чистовий РЕ, який розміщений в осьовому напрямі на найбільшій відстані від торця фрези, а в радіальному напрямі - на найменшій відстані від осі фрези $(r)$. 
Характерною особливістю торцевого фрезерування (рис. 2) є неоднакова шорсткість за шириною обробки. Теоретична висота мікронерівностей обробленої поверхні (ії геометрична складова) на певній базовій лінії залежить від ії положення і розраховується за формулою:

$$
R z=\frac{S^{2}\left(r^{2}-x^{2}\right)}{8 R r^{2}},
$$

де $r$ - радіальне розташування формоутворюючого чистового РЕ, мм;

$x$ - відстань від осі фрези до базової лінії на площині, на якій вимірюється шорсткість, мм.

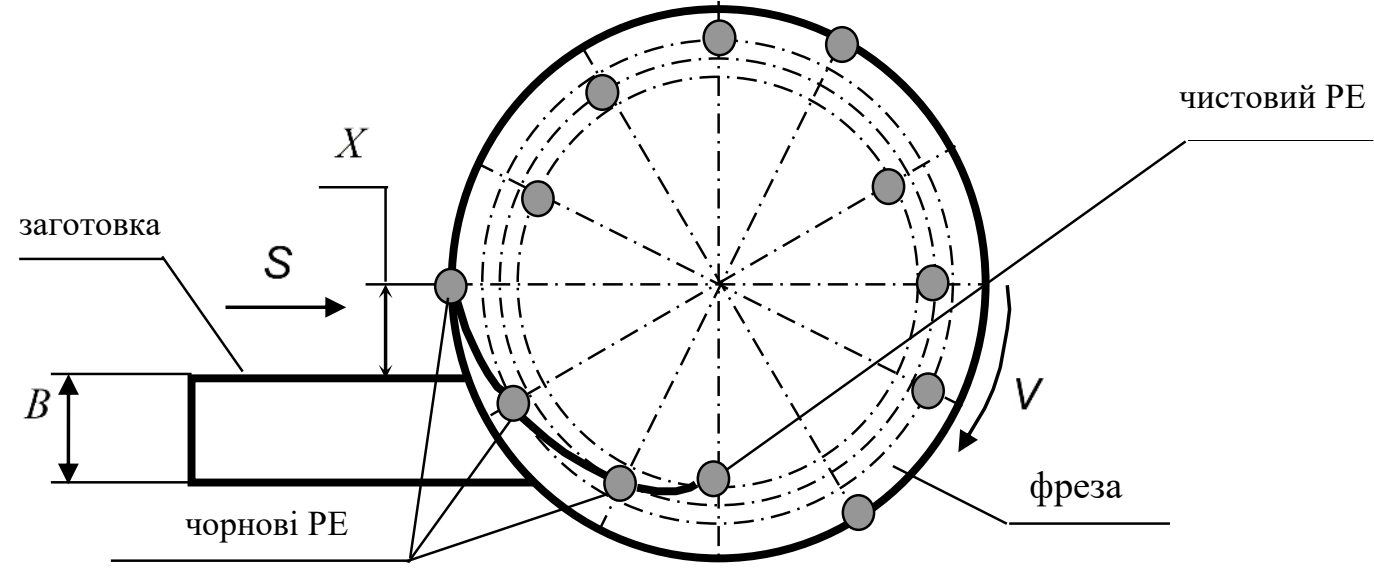

Рис. 2. Схема розташування ториевої ступінчастої фрези косокутного різання відносно заготовки

Із залежності (1) видно, що при збільшенні відстані від осі фрези висота мікронерівностей зменшується, що може бути використано для підвищення якості обробки деталей, ширина яких менша ніж радіус, на якому розташований формоутворюючий РЕ фрези. Під час фрезерування площин, ширина яких більша за радіус фрези $B>r$, найбільша висота мікронерівностей буде виникати у площині, що проходить через вісь фрези.

За залежністю (1) визначимо теоретичну висоту мікронерівностей $R z$ для профілювання поверхні різальним елементом з радіусом задньої циліндричної поверхні $R=10$ мм при подачах на зуб $S_{1}=1$ мм/зуб та $S_{2}=2$ мм/зуб (табл. 2). Враховуючи, що профілювання поверхні здійснюється тільки одним різальним елементом, то подача на оберт дорівнює подачі на зуб.

Таблиия 2

Залежність теоретичної висоти мікронерівностей від величини зміщення деталі щуодо центра фрези

\begin{tabular}{|c|c|c|c|c|c|c|c|c|c|c|c|}
\hline \multirow{3}{*}{$\begin{array}{c}\text { Подача, } \\
\text { мм/об }\end{array}$} & \multicolumn{11}{|c|}{ Теоретична висота мікронерівностей, мкм } \\
\hline & \multicolumn{11}{|c|}{ при зміщенні заготовки відносно осі фрези, мм } \\
\hline & 0 & 10 & 20 & 30 & 40 & 50 & 60 & 70 & 80 & 90 & 100 \\
\hline 1,0 & 12,5 & 12,4 & 12,0 & 11,4 & 10,5 & 9,4 & 8,0 & 6,4 & 4,5 & 2,4 & 0,0 \\
\hline 2,0 & 50,0 & 50,0 & 48,0 & 45,5 & 42,0 & 37,5 & 32,0 & 25,5 & 18,0 & 9,5 & 0,0 \\
\hline
\end{tabular}

Результати теоретичних обчислень показують, що отримати шорсткість обробленої поверхні $R z=12,5$ мкм можна за рахунок зміщення до 90 мм заготовки малої ширини при збільшенні подачі 3 $S_{1}=1$ мм/зуб до $S_{2}=2$ мм/зуб. Таким чином досягається підвищення продуктивності обробки поверхні деталі малої ширини у 2 рази. Разом з тим, необхідно враховувати, що при симетричному і зміщеному розташуваннях заготовки відносно фрези змінюються параметри зрізуваного шару та характеристики процесу стружкоутворення, що вимагає додаткових досліджень для різних матеріалів. Результати експериментальних даних [6] показують, що незалежно від пластичних характеристик оброблюваних матеріалів зміщення заготовки відносно торцевої фрези, оснащеної НТМ, діаметром 250 мм призводить до зменшення дійсної висоти мікронерівностей (табл. 3).

Таблиияя 3

Залежність шорсткості обробленої поверхні від зміщення заготовки відносно ториевої фрези

\begin{tabular}{|c|c|c|c|c|c|c|}
\hline \multirow{2}{*}{$\begin{array}{c}\text { Оброблюваний } \\
\text { матеріал }\end{array}$} & \multicolumn{5}{|c|}{$R a$ (мкм) при зміщенні заготовки відносно осі фрези $X$ (мм) } \\
\cline { 2 - 7 } & 0 & 20 & 40 & 60 & 80 & 100 \\
\hline чавун СЧ21 & 1,18 & 1,18 & 1,12 & 0,94 & 0,80 & 0,74 \\
\hline сталь 45 (54...56 HRC) & 1,20 & 1,19 & 1,13 & 1,00 & 0,95 & 0,90 \\
\hline
\end{tabular}


Залежність шорсткості обробленої плоскої поверхні заготовки із сталі Р6М5 при ії зміщенні відносно торцевої фрези за різних значень подачі на зуб показана в таблиці 4.

Таблиия 4

Залежність шорсткості обробленої поверхні від зміщення заготовки відносно ториевої фрези при різних подачах

\begin{tabular}{|c|c|c|c|}
\hline \multirow{2}{*}{ № } & \multirow{2}{*}{ Подача на зуб $S_{Z}$, мм/зуб } & Шорсткість поверхні $R a$ (мкм) від зміщення $X$ (мм) \\
\cline { 2 - 4 } & 0,25 & $X=0$ & $X=120$ \\
\hline 1 & 0,32 & 1,180 & 0,883 \\
\hline 2 & 0,40 & 1,340 & 1,090 \\
\hline 3 & 0,50 & 1,700 & 1,200 \\
\hline 4 & 0,63 & 3,050 & 1,380 \\
\hline 5 & 0,75 & 3,670 & 1,755 \\
\hline 6 & & 5,200 & 2,785 \\
\hline
\end{tabular}

Дані таблиць 3-4 показують, що за рахунок несиметричного розташування заготовки відносно торцевої фрези є можливість підвищити якість обробленої поверхні та застосовувати значно більші подачі, що забезпечує збільшення продуктивності обробки.

Разом з тим, при несиметричному розташуванні заготовки відносно торцевої фрези збільшується довжина ділянки врізання фрези в заготовку, що може збільшити час обробки деталей.

Час обробки деталей при симетричному фрезеруванні:

$$
t_{1}=\frac{L+r-\sqrt{r^{2}-0,25 B^{2}}}{n_{1} S_{1}},
$$

де $L$ - довжина деталі, мм;

$n_{1}$ - частота обертання торцевої фрези при симетричному фрезеруванні, $\mathrm{xB}^{-1}$,

$S_{1}$ - подача на оберт при симетричному фрезеруванні.

Час обробки деталі при несиметричному фрезеруванні:

$$
t_{2}=\frac{L+\sqrt{r^{2}-x^{2}}-\sqrt{r^{2}-(x+B)^{2}}}{n_{2} S_{2}},
$$

де $n_{2}$ - частота обертання торцевої фрези при несиметричному фрезеруванні, $\mathrm{xB}^{-1}$,

$S_{2}$ - подача на оберт при несиметричному фрезеруванні.

Враховуючи, що при несиметричному фрезеруванні збільшується довжина ділянки врізання торцевої фрези, підвищення продуктивності можливе за рахунок збільшення частоти обертання $n_{2}$ фрези та подачі на оберт. Експериментальні дані (табл. 4) показують, що при несиметричному розміщенні деталі відносно фрези подача по відношенню до симетричного фрезерування може бути збільшена у 2 і більше разів, що забезпечить збільшення продуктивності.

Максимальна величина зміщення деталі відносно осі торцевої фрези не має перевищувати значення:

$$
x=r-B-5,
$$

де 5 - це максимальна похибка розташування заготовки відносно торцевої фрези, мм.

Необхідний діаметр фрези для обробки деталей малої ширини (20...50 мм) може бути розрахований за формулою:

$$
D_{1}=\frac{1000 V_{o p t}}{\pi \cdot n_{\max }},
$$

де $D_{1}$ - розрахункове значення необхідного діаметра фрези, мм;

$V_{\text {opt }}$ - оптимальне значення швидкості різання для обробки деталей з різними фізико-механічними характеристиками, м/хв;

$n_{\max }$ - максимально допустима частота обертання шпинделя верстата, на якому виконується обробка, $\mathrm{xB}^{-1}$.

Розрахункове значення діаметра торцевої фрези за залежністю (5) округлюється до найближчого більшого із ряду діаметрів фрез $D$.

Після підстановки значень $n_{2}=n_{\max }, r=\frac{D}{2}, x=r-B-5$ та $S_{2}$ у формулу (3) перевіряється умова збільшення продуктивності обробки деталі малої ширини: $t_{2}<t_{1}$.

Висновки та перспективи подальших досліджень. Проведений аналіз показує, що застосування процесів обробки плоских поверхонь деталей торцевими фрезами, оснащеними надтвердими матеріалами, дозволяє підвищити продуктивність обробки та зменшити кількість дефектів поверхневих шарів по відношенню до процесів абразивної обробки. 
1. Значні переваги мають процеси чистової обробки плоских поверхонь торцевими фрезами косокутного різання з використанням ступінчастих схем різання, які дозволяють забезпечити повну участь у процесі обробки всіх різальних елементів фрез, покращити динаміку процесу різання та підвищити стійкість інструмента.

2. Застосування безвершинної геометрії з монотонними криволінійними різальними кромками дозволяє виключити із процесу формування мікронерівностей найбільш вразливу ділянку різальної кромки - вершину, що підвищує надійність процесу одержання необхідної шорсткості оброблених плоских поверхонь.

3. Аналіз процесів обробки плоских поверхонь деталей малої ширини (20..50 мм) торцевими фрезами малого діаметра показує, що зазначені процеси супроводжуються такими недоліками: незначна кількість різальних елементів, які одночасно беруть участь у різанні; погіршена динаміка процесів фрезерування; неоптимальні швидкості різання, що призводить до зниження зносостійкості різальних елементів та надійності процесів обробки тощо.

4. Обгрунтовано доцільність використання для обробки плоских поверхонь деталей малої ширини торцевих фрез збільшених діаметрів, оснащених НТМ, розміри яких розраховуються за рекомендованими оптимальними значеннями швидкостей різання та максимально можливими частотами обертання шпинделів верстатів, на яких реалізується процес обробки.

5. Визначені шляхи підвищення продуктивності обробки поверхонь малої ширини застосуванням фрез збільшеного діаметра на невисокошвидкісних верстатах та зміщенням деталей відносно осі фрези на відстань, що гарантує забезпечення необхідної висоти мікронерівностей обробленої поверхні.

6. Під час подальших досліджень планується розглянути характер формоутворення макро- i мікропрофілю оброблених поверхонь деталей з різними фізико-механічними властивостями для процесів чистового торцевого фрезерування.

Список використаної літератури:

1. Сенькин Е.Н. Конструкции и эксплуатация фрез, оснащенных композитами / Е.Н. Сенькин, Г.В. Филиппов, A.B. Колядин // Библиотека фрезеровщика. - Л. : Машиностроение, 1988. - 63 с.

2. Прогрессивные режущие инструменты и режимы резания металлов / В.И. Баранчиков, А.В. Жаринов, Н.Д. Юдина, А.И. Садыхов. - М. : Машиностроение, 1990. - 400 с.

3. Конструкции и эксплуатация торцовых фрез из сверхтвердых материалов на основе нитрида бора. Методические рекомендации. - М. : НИИмаш, 1984. - 66 с.

4. Подураев В.Н. Эффективность обработки резанием с опережающим пластическим деформированием / В.Н. Подураев, В.Н. Ярославцев, Н.А. Ярославцев // Вестник машиностроения. - 1972. - № 12 - С. 58-61.

5. Виговський Г.М. Використання кінематичних схем різання при чистовому торцевому фрезеруванні / Г.М. Виговський, П.П. Мельничук, О.А. Громовий // Вісник ЖІТІ. Технічні науки. - 2000. - № 13 - С. $26-31$.

6. Виговський Г.М. Підвищення працездатності торцевих фрез для чистової обробки плоских поверхонь : автореф. дис. на здобуття наук. ступеня канд. техн. наук : спец. 05.03.01 «Процеси механічної обробки, верстати та інструменти» / Виговський Георгій Миколайович. - Київ, 2000. - 16 с.

7. Громовий O.A. Розробка чистових косокутних торцевих фрез з комбінованими схемами різання : дис. на здобуття наук. ступеня канд. техн. наук : спец. 05.03.01 / Громовий Олексій Андрійович. - Київ, 2002. - 172 с.

8. Лоєв В.Ю. Удосконалення комбінованого методу обробки плоских поверхонь деталей різанням i поверхневим пластичним деформуванням / В.Ю. Лоєв // Вісник ЖДТУ. - 2004. - Вип. 2 (29). - С. 29-36.

9. Безвершинне косокутне фрезерування. Зношення та стійкість / Г.М. Виговський, О.А. Громовий, П.П. Мельничук, В.С. Ольшевський // Вісник ЧІТІ. - 2000. - № 4. - С. 4-5.

10. Спосіб плоского фрезерування торцевими фрезами : деклараційний патент на винахід 40156 А Україна, В23С3/00 / Г.М. Виговський, О.А. Громовий, В.Ю. Лоєв, П.П. Мельничук (Україна). - № 2000074236 ; заявлено 17.07.2000 ; опубл. 16.07.2001, Бюл. № 16.

11. Підвищення ефективності обробки плоских поверхонь фрезеруванням / П.П. Мельничук, Г.М. Виговський, О.А. Громовий та ін. ; під ред. П.П. Мельничука. - Житомир : ФОП Євро-Волинь, 2017. - 287 с.

12. Structural improvement of face mills designs based on systems approach / L.Hlembotska, N.Balytska, P. Melnychuk, H.Vyhovskyi // Scientific Journal of TNTU. - Tern. : TNTU, 2021. - Vol. 101. - No 1. - P. 102-114 [Electronic resource]. - Access mode : https://visnyk.tntu.edu.ua/?art=597.

13. Modelling the loading of the nose-free cutting edges of face mill with a spiral-stepped arrangement of inserts / L. Hlembotska, P.Melnychuk, N.Balytska, O.Melnyk // Eastern-European Journal of Enterprise Technologies. 2018. - Vol. 1. (1 (91)). - P. 46-54. DOI: 10.15587/1729-4061.2018.121712.

14. Computer modelling power load of face mills with cylindrical rake face of inserts in machining difficult-to-cut materials / L.Hlembotska, N.Balytska, P.Melnychuk, O.Melnyk // Scientific Journal of TNTU (Tern.). - 2019. Vol. 93. - No. 1. - P. 70-80. DOI.: 10.33108/visnyk_tntu2019.01.070.

15. Громовий O.A. Шляхи удосконалення процесу обробки плоских поверхонь деталей фрезеруванням / О.А. Громовий, Г.М. Виговський, Н.О. Балицька // Технічна інженерія. - 2020. - № 2 (86). - С. 48-53. DOI: $10.26642 /$ ten-2020-2(86)-48-53. 


\section{References:}

1. Sen'kin, E.N., Filippov, G.V. and Kolyadin, A.V. (1988), «Constructions and operation of mills equipped with composites», Milling Machine Library, 63 p.

2. Baranchikov, V.I., Zharinov, A.V., Yudina, N.D. and Sadykhov, A.I. (1990), Advanced cutting tools and metal cutting modes, Mashinostroenie, M., $400 \mathrm{p}$.

3. Design and operation of face mills equipped with superhard materials based on boron nitride. Methodical recommendations (1984), NIImash, M., 66 p.

4. Poduraev, V.N., Yaroslavtsev, V.N. and Yaroslavtsev, N.A. (1972), «Cutting efficiency with advanced plastic deformation», Vestnik mashinostroeniya, No. 12, pp. 58-61.

5. Vygovs'kyj, G.M., Mel'nichuk, P.P. and Gromovij, O.A. (2000), «The use of kinematic cutting schemes in finishing face milling», Bulletin of ZhITI, No. 13, pp. 26-31.

6. Vygovs'kyj, G.M. (2000), «Improving the efficiency of face mills for the finishing of flat surfaces», Abstract of Ph.D. dissertation, NTUU «KPI», $16 \mathrm{p}$.

7. Gromovyj, O.A. (2002), «Development of finishing face mills with combined cutting schemes», Ph.D. Thesis of dissertation, 05.03.01, ZhITI, $172 \mathrm{p}$.

8. Lojev, V.Yu. (2004), «Improvement of the combined method of machining of flat surfaces of parts by cutting and surface plastic deformation», Bulletin of ZhDTU, Issue 2 (29), pp. 29-36.

9. Vygovs'kyj, G.M., Gromovyj, O.A., Mel'nychuk, P.P. and Ol'shevs'kyj, V.C. (2000), «Inverted Oblique Milling. Wear and stability», Bulletin of ChITI, No. 4, pp. 4-5.

10. Vygovs'kyj, G.M., Gromovyj, O.A., Lojev, V.Ju. and Mel'nychuk, P.P. (2001), The method of flat milling by face mills, Declarative patent for the invention 40156 A Ukraine, B23C3/00 (Ukraine), No. 2000074236, Claimed July 17, 2000, Publ. 16.07.2001, Bull. No.16.

11. Mel'nychuk, P.P., Vygovs'kyj, H.M., Gromovyj, O.A.et al. (2017), «Improving the efficiency of machining flat surfaces by milling», in Mel'nychuk, P.P. (ed.), FOP Euro-Volyn, Zhytomyr, 287 p.

12. Hlembotska, L., Balytska, N., Melnychuk, P., and Vyhovskyi, H. (2021), «Structural improvement of face mills designs based on systems approach», Scientific Journal of TNTU, Vol. 101, No. 1, pp. 102-114. Режим доступу : https://visnyk.tntu.edu.ua/?art=597

13. Hlembotska, L., Melnychuk, P., Balytska, N. and Melnyk, O. (2018), «Modelling the loading of the nose-free cutting edges of face mill with a spiral-stepped arrangement of inserts», Eastern-European Journal of Enterprise Technologies, Vol. 1 (1 (91)), pp. 46-54, doi: 10.15587/1729-4061.2018.121712.

14. Hlembotska, L., Balytska, N., Melnychuk, P. and Melnyk O. (2019), «Computer modelling power load of face mills with cylindrical rake face of inserts in machining difficult-to-cut materials», Scientific Journal of TNTU, Vol. 93, No. 1, pp. 70-80, doi: 10.33108/visnyk_tntu2019.01.070.

15. Gromovyj, O.A., Vygovs'kyj, G.M. and Balyc'ka, N.O. (2020), «Shljahy udoskonalennja procesu obrobky ploskyh poverhon' detalej frezeruvannjam», Tehnichna inzhenerija, No. 2 (86), pp. 48-53, doi: 10.26642/ten-2020-2(86)-48-53.

Виговський Георгій Миколайович - кандидат технічних наук, професор Державного університету «Житомирська політехніка».

http://orcid.org/0000-0002-2199-5129.

Наукові інтереси:

- обробка матеріалів різанням;

- проєктування різальних інструментів.

Громовий Олексій Андрійович - кандидат технічних наук, доцент Державного університету «Житомирська політехніка».

http://orcid.org/0000-0002-2761-0736.

Наукові інтереси:

- обробка матеріалів різанням;

- проєктування різальних інструментів.

Балицька Наталія Олександрівна - кандидат технічних наук, доцент Державного університету «Житомирська політехніка».

http://orcid.org/0000-0003-1363-8110.

Наукові інтереси:

- обробка матеріалів різанням;

- проєктування різальних інструментів.

Глембоцька Лариса Євгенівна - кандидат технічних наук, доцент Державного університету «Житомирська політехніка». http://orcid.org/0000-0002-7234-4246.

Наукові інтереси:

- обробка матеріалів різанням;

- проєктування різальних інструментів. 